\title{
Hydromass in Natural-Territorial Complexes in the Upper- and High-Mountain Landscapes of the lalno Ridge
}

\author{
Robert Maghlakelidze $^{1, ~ *, ~ G i o r g i ~ M a g h l a k e l i d z e ~}{ }^{1}$, Revaz Tolordava ${ }^{2}$, Malkhaz Gvinjilia ${ }^{2}$, \\ Koba Korsantia ${ }^{2}$ \\ ${ }^{1}$ Department of Geography, TSU, Tbilisi, Georgia \\ ${ }^{2}$ Department of Geography, Sukhumi State University, Tbilisi, Georgia \\ Email address: \\ robert.maghlakelidze@tsu.ge (R. Maglakelidze),rezo_06@mail.ru (R. Tolordava),malkhazgvinjilia@gmail.com (M. Ghvinjilia), \\ kob1973@mail.ru (K. Korsantia) \\ *Corresponding author
}

\section{To cite this article:}

Robert Maghlakelidze, Giorgi Maghlakelidze, Revaz Tolordava, Malkhaz Gvinjilia, Koba Korsantia. Hydromass in Natural-Territorial Complexes in the Upper- and High-Mountain Landscapes of the Ialno Ridge. Earth Sciences. Vol. 6, No. 6, 2017, pp. 106-110. doi: 10.11648/j.earth.20170606.11

Received: July 18, 2017; Accepted: July 19, 2017; Published: September 29, 2017

\begin{abstract}
The study of hydromass in natural-territorial complexes in the upper-mountain and high-mountain landscapes of the Ialno Ridge is based on the analysis spatial-temporal concept of natural-territorial complexes (NTCs), which was developed by Prof. Nikoloz Beruchashvili. This question allows analyzing and evaluating the following issues: moisture circulation and soil hydromasses in different NTCs. The study is based on the long-term field work conducted by the staff of Martkopi physical-geographical station. On the basis of the research some peculiarities of the territorial distribution of soil hydromasses were revealed. The maximum amount of the soil hydromasses $(1733 \mathrm{t} / \mathrm{ha})$ is registerd in the facies of the northern exposition and moderately slanting slopes with beech forest and litterfall, whereas the mean value is $1421 \mathrm{t} / \mathrm{ha}$. In the soils of the facies spread at the top of the Ialno Ridge the maximum hydromass amount is $1173 \mathrm{t} / \mathrm{ha}$ and the mean value is $887 \mathrm{t} / \mathrm{ha}$. But in the soils of the slanting tops with southern exposition presented as mixed grass meadows the maximum hydromass amount is $676 \mathrm{t} / \mathrm{ha}$ and the mean value is $633 \mathrm{t} / \mathrm{ha}$. The research shows that in the NTCs with of the high-mountain subalpine and upper-mountain forest landscapes the hydromass amounts depend on humidity and pedomass amount in separate geohorizons of the soils. Besides, hydromass amount in soil is influenced by the following factors: exposition and declination of the slope, the thickness of the soil profile, behaviour of moisturizing, projection vegetation cover and facies, nano-forms of the relief. High amount of hydromasses is characteristic of the gorges on the southern exposition slopes (more than $2000 \mathrm{t} / \mathrm{ha}$ ). The hydromass amount is also high (1500-2000 t/ha) in the beech forests in the natural-territorial complexes of the northern and southern exposition slopes. The amount of hydromasses is low (500-1000 t/ha) at the top of the Ialno Ridge and the subalpine meadows in the natural-territorial complexes of the southern exposition slopes. The same hydromass amount is observed in the vegetation semi-associations in the natural-territorial complexes of the slopes of the White Cliff. The hydromass amount is the least (less than $500 \mathrm{t} / \mathrm{ha}$ ) in rocky natural-territorial complexes.
\end{abstract}

Keywords: Natural-Territorial Complexes, Soil Hydromasses, Ialno Ridge

\section{Introduction}

Among problems of landscape sciences, one of most significant is an estimation of resource potential and modern condition of landscapes. Significant role in the decision of this problem play study of hydromass in natural-territorial complexes and Moisture circulation.
Moisture circulation, like solar energy transformation, biocycle and gravigenic processes, is one of the most significant functional processes in natural-territorial complexes. A functional process is a unity of all the processes of substance and energy. Moisture circulation in Nikoloz Beruchashvili's general scheme [1] is considered as a unity of active hydromass flows in natural-territorial 
complexes.

Hydromasses are masses of water, which appear in solid, liquid and gasous forms in natural-territorial complexes. The amount of hydromasses is expresses by correlation of absolute weight unit and area unit $-\mathrm{t} / \mathrm{ha}$.

Analysis of NTCs and their components requires studying of all structural units formed during the process of synthesis of elementary structural-functional parts - geomasses in space and time and determining the regularities of mutual relations taking place in landscapes. It is important to identify and determine the mutual influence of different characteristics combined in the field of study of Landscape disciplines (Geomorphology, Climatology, Soil Science, Phytocenology, Ecology, etc.). These characteristics are presented as the species of the vegetation cover, acidity of the soil $(\mathrm{pH})$, humus type, soil moisture [1].

During moisture circulation processes active hydromasses move in the forms of liquid and solid precipitations in the surface layer of the atmosphere. Due to interrelationship with other geomasses certain transformation takes place in these precipitations, namely, they are kept by vegetation cover. The precipitations, which appear on the Earth's surface, are spent on surface runoff water, infiltration in the soil and underground runoff. Some part of them is accumulated in the underground layer of the profile of natural-territorial complexes that leads to increase of hydromass concentration in soil. On the contrary, the concentration of hydromasses decreases in soil as a result of total evaporation. Total evaporation includes transpiration and physical evaporation. Transpiration takes place in plants and physical evaporation occurs on soil surface. During certain yearly seasons some natural-territorial complexes are covered with snow. The amount of hydromasses increases due to precipitation fall and decreases when the snow cover melts. In the regions, where the climate is more continental and winter is colder, frozen hydromasses are observed in the soil. These hydromasses undergo the same dynamics. A general scheme of moisture circulation is designed for a yearly part of time. We may provide a moisture circulation scheme for separate states of natural-territorial complexes [1].

In natural-territorial complexes one of the main geomasses of moisture circulation is hydromass in soil. Geomasses are elementary structural-functional parts of natural-territorial complexes. They are characterized with certain "mission", specific functional tasks and also the speed of variation in time or motion in space. There are seven types of geomasses distinguished in natural-territorial complexes: pedomasses, phytomasses, zoomasses, mortmasses, hydromasses, aeromasses and lithomasses. The result of the synthesis of geomasses and functional processes is the existence of comparatively homogenous layers of geohorizons in the vertical profile of natural-territorial complexes. These geohorizons are characterized with a set of landscapegeophysical properties, among which the most important are specific convergence and coordination of geomasses. One of the most essential components of the moisture circulation and productive geomasses in the whole vertical profile of geohorizons and natural-territorial complexes are the hydromasses in soil [2].

Hydromass is one of the best landscape-geophysical properties to use to characterize a number of properties of NTCs and number of natural processes in them (moisture circulation, degree of aridization or humidization in landscapes, deficit of moisture, overwettinh, etc.).

\section{Methods and Initial Data}

In work, landscapes of Ialno Ridge are examined at the faices and types of vertical structure of NTC. A study is based to the landscape map and field observations, carried out Martkopi Physical-geographical Station, Tbilisi State University. In collection of field materials participated author. These field materials cover entire spectrum landscapes of Ialno Ridge, beginning from hoothills and ending sub-alpine and landscapes.

The study of hydromass in natural-territorial complexes in the upper-mountain and high-mountain landscapes of the Ialno Ridge is based on the analysis spatial-temporal concept of natural-territorial complexes (NTCs), which was developed by Prof. Nikoloz Beruchashvili. The main value of this methodology is that having based on unified methods it enables investigating natural components, state of NTCs, peculiarities of structure and functionality, current state of landscapes and degree of anthropogenic transformation; elaborating spatial-temporal forecasting models for NTCs, etc. [3].

The study of hydromass mostly relies upon the description of field plots and semi-stationary observations of Ialno Ridge' landscapes. Most of these observations were described during the same daily conditions of the NTCs (specifically, during the summer) allowing us to compare them. In addition, the materials of various literary sources $[3,4]$.

On the basis of the data of the Ialno Physical-Geographical semi-station and our studies we conducted a work that enabled us to determine the amount of hydromasses in the soil in the upper-mountain and subalpine landscapes of the Ialno Ridge.

Detailed stationary studies took place on the territory of the fixed station. A meteorological station was constructed on four base points on the territory of the fixed station (in the subalpine landscapes of the low, middle and upper mountain forests and the erosive-denudational circus of the White Cliff) of the Ialno Ridge, where continuous decadal observations took place. Besides, observations were carried out in order to study vertical and horizontal structures on the experimental plots and the transect area.

In the areas of the fixed station observations take place along the transect, where readings for different parameters are obtained regularly and simultaneously in time on the preliminarily selected study plots. Studies conducted along the transect are mainly route-like, though it includes periodic observations. It means that the transect trajectory is constructed in advance and periodic observations take place 
at one and the same place selected preliminarily.

Nowadays ordination geographical studies, i.e., geographical studies for certain purposes, are carried out in certain periods of a year.

In order to determine the hydromass amount in the soil, in the first place, humidity in the soil was determined. Samples from the soil were taken at following depths: 0-5, 5-10, 10$15,15-20,20-30,35-40,45-50,55-60,65-70,75-80,85-90$, 95-100 cm, among them at 0-5, 5-10, 10-15, 15-20 and 25-30 $\mathrm{cm}$ depths - two samples at each. For samples their precise weights were determined. First, the samples were dried in special equipment. The drying process usually took 5-7 hours at $100-105^{\circ} \mathrm{C}$. Later the samples were weighed [5].

The peculiarities of terririal distribution of the hydromass were identified by different aspects:

(1) the mutual connections between the hydromass and the physical-geographical factors;

(2) the physical-geographical factors determining the accumulation of maximum or minimum quantities of hydromass;

(3) the mutual connections between the hydromas and degree of NTCs.

As these works suggest, the average amounts of hydromass are analyzed according to facies and are given in ton/hectare unit.

\section{Research Object}

The Ialno Physical-Geographical Fixed Station is located in the upper-mountain forest and subalpine landscapes of the Ialno Ridge, in $40 \mathrm{~km}$ distance from Tbilisi, on the Ialno Ridge Scientific Geographical Testing Area of Iv. Javakhishvili Tbilisi State University. The area covers 100 $\mathrm{km}^{2}$. It consists of the territory of the Martkopi PhysicalGeographical Fixed Station in the foothill steppe landscapes ( $930 \mathrm{~m}$ above sea level), the transect, which crosses all the landscapes of the Ialno Ridge from foothill steppe landscapes to the subalpine landscapes (from $900 \mathrm{~m}$ to $1874 \mathrm{~m}$ above sea level) and the Ialno Fixed Station itself, which is located in the subalpine and upper-mountain forest landscapes $(1750 \mathrm{~m}$ above sea level). The data of the scientific geographical testing area serve as models for the whole region of East Transcaucasia as far as in this region, except alpine and nival landscapes, all the natural-territorial complexes of East Transcaucasia are presented.

The territory of the Ialno Fixed Station has a rectangular form and is built of upper Sarmatian, also Pontian and Meotice layers. Tectonically the Ialno Ridge is a horstsyncline as a whole. It, with its highest point (Mount Ialoni or Ialno, $1874 \mathrm{~m}$ above sea level) belongs to the type of middle height mountains. The climate of the fixed station territory is moderately humid, with cold winter and long cold summer, two minimums of precipitations per year, transient to short summer climate. On the territory any continuous streams are not observed. There are only springs and episodic streams. The maximum runoff is observed in April. It is caused by fast melting of snow. Subalpine meadows, also tall herbaceous plants and subalpine shrubbery are dominating in the areas of the fixed station. There are beech and beechhornbeam forests in the upper mountains of the Ialno Ridge. In the forests of the Saguramo-Ialno Ridge we can meet deer, roe deer, rarely - grizzly, Caucasian wolf, jackal, mountain fox, forest cat, Caucasian falcon, hawk, sparrow hawk and etc. In the vicinities of the fixed station dark grey forest soil is observed under the forest. Under the subalpine vegetation cover there are mountain-forest-meadow soils [6].

\section{Main Results}

\subsection{Main Landscapes of Ialno Ridge}

The territory $\left(0.41 \mathrm{~km}^{2}\right)$ of the Ialno Fixed Station is rich in landscapes. There are 29 facies types, which are combined in 12 holes, 4 regions and 3 places. Upper-mountain forest and upper-mountain subalpine landscapes are presented on the territory of the fixed station [6].

On the territory of the Ialno Fixed Station, within the framework of a stationary study programme, the soil dampness was studies in dynamics during the many years. The amount of hydromasses in the soil was studies in details in 1986, 2006 and 2016 in below 10 dominant facies in the periods of JuneJuly, during the humid structure stabilization state period in summer, when the structure and functioning of a naturalterritorial complex is not characterized with rapid changes. The total number of the areas studied by us was 21 . In some facies we studied only one area in each and 2-3 areas in larger facies. On the territory of the Ialno Fixed Station we studied the amount of the soil hydromasses in the following facies:

(1) Moderately slanting slopes with northern exposition, transeluvial regime and forests of beech forest and litterfall;

(2) Mountain tops with autonomous regimes, meadows of pulses, grains and mixed grass;

(3) Slanting mountain tops with southern exposition, transeluvial regime, meadows of pulses, grains and mixed grass;

(4) Moderately slanting slopes with southern exposition, transeluvial regime, meadows of pulses, grains and mixed grass;

(5) Gorges on the southern exposition slopes with transeluvial regime, shrubbery and mixed grass meadows;

(6) Gorges in the southern exposition slopes with transeluvial regime and broadleaf beech forests;

(7) Steep slopes with south-western exposition, transeluvial regime and forests of beech and hornbeam;

(8) Gorges with transeluvial regime and forests of broadleaf beech and hornbeam;

(9) Slanting mountain tops with southern exposition, transeluvial regime and beech and shrubbery forests;

(10) Moderately slanting slopes with southern exposition, transeluvial regime and meadows of grains, pulses and grass cover. 


\subsection{Amount of Hydromass According to Facies of Ialno Ridge}

Amount of hydromasses mainly depend on soil humidity and pedomass amount. However, for the vegetation cover the hydromass amount, which is accumulated during vegetation period, also the moisture amount in upper horizons of the soil, are very significant. Therefore, it is more important to study the hydromass amount in the upper horizons of soil (AB humus horizon) as well. Soil humidity is a limited factor in the distribution of natural-territorial complexes. The highest average yearly humidity $(27-29 \%)$ is observed in holes with forest derivatives. Values of soil humidity on steep slopes and sibljak holes are approximately the same. It is obvious that minimum humidity must be on the slopes nearer to the tops with phrygana plants $(21-25 \%)$.

It is well known that maximum hydromass amount is accumulated in hydrothermal landscapes - bogs, river terraces and other river-bank facies. Such territories are not presented in upper and high mountains of the Ialno Ridge. However, the hydromass amount is quite high here. It is noteworthy that in upper mountain landscapes the hydromass amount is also high. It can be explained by two facts [4]:

High humidity in the air and soil in accordance with the increase of absolute height;

Great amount of pedomasses.

The same factors explain comparatively high amount of hydromasses on the study area.

As the analysis of the hydromass amount shows the most amount (1900 t/ha) of them are observed in gorges, where forest derivatives have preserved, in hollows with meadow plants and subalpine vegetation at the top of the ridge (Figure 1). At the same time there is minimum hydromass amount on the tops and slopes with phrygana plants near the tops (Figure 1).

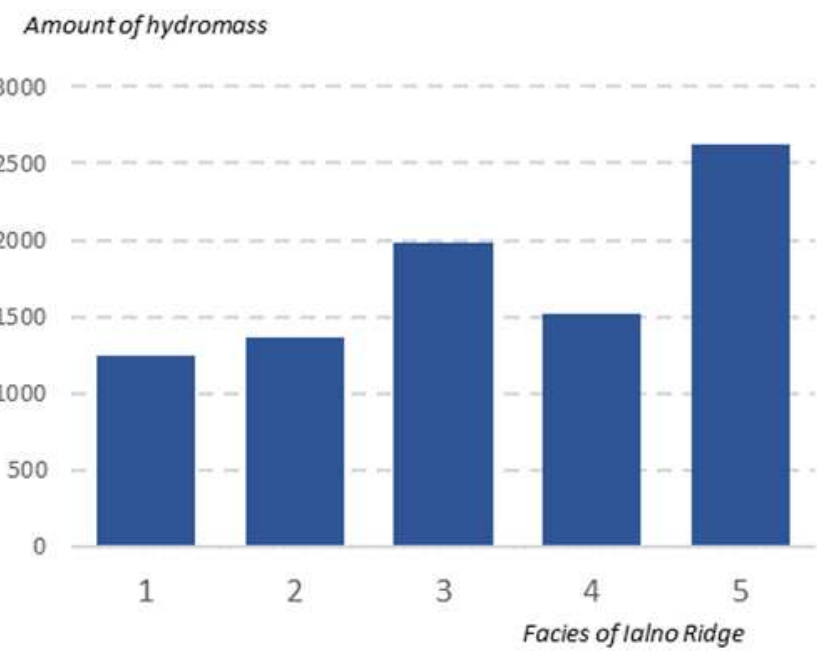

Figure 1. Average amount of hydromasses of Ialno Ridge.

In the facies of the northern exposition and moderately slanting slopes with beech forest and litterfall the maximum amount of the soil hydromasses is $1733 \mathrm{t} / \mathrm{ha}$, whereas the mean value is $1421 \mathrm{t} /$ ha (Figure 2). In separate geohorizons of the soil the hydromass amounts are distinctly different. In $0-10 \mathrm{~cm}$ soil layer the hydromass amount is $600 \mathrm{t} / \mathrm{ha}$, in 10 $40 \mathrm{~cm}$ soil layer it is $404 \mathrm{t} / \mathrm{ha}$ and in $40-100 \mathrm{~cm}$ soil layer it is $164 \mathrm{t} / \mathrm{ha}$.

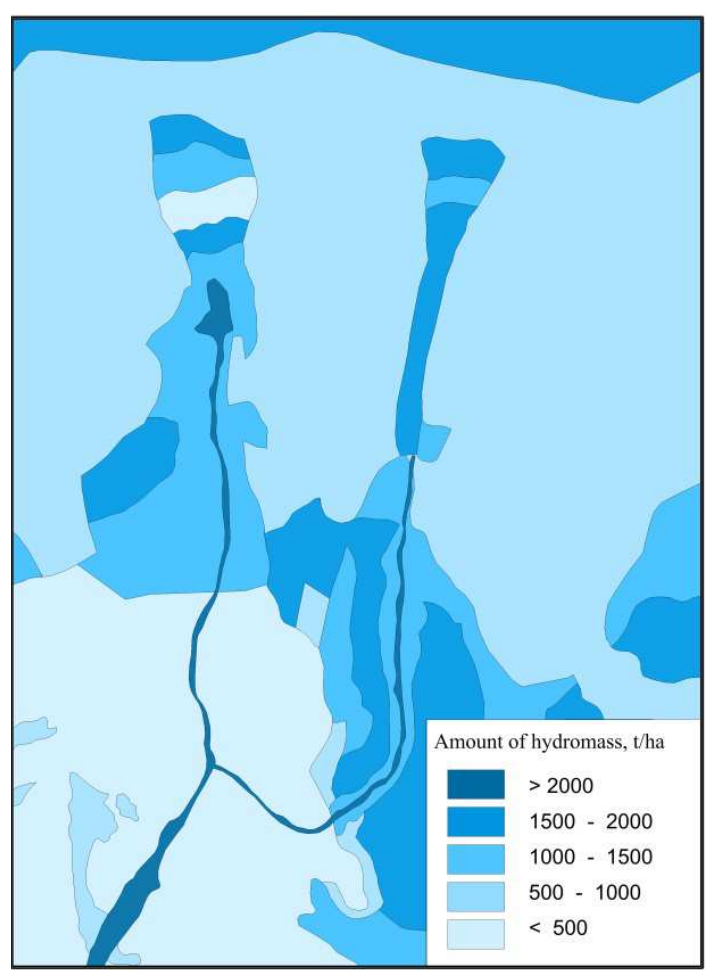

Figure 2. Hydromasses of Ialno Ridge.

In the soils of the facies spread at the top of the Ialno Ridge the maximum hydromass amount is $1173 \mathrm{t} / \mathrm{ha}$ and the mean value is $887 \mathrm{t} / \mathrm{ha}$. According to geohorizons the amount of hydromasses in the soils at $0-10 \mathrm{~cm}$ depth is $352 \mathrm{t} / \mathrm{ha}$, in $10-40 \mathrm{~cm}$ soil layer it is $672 \mathrm{t} / \mathrm{ha}$ and in $40-100 \mathrm{~cm}$ layer it is $192 \mathrm{t} / \mathrm{ha}$.

Facies: 1 - Mountain tops with dry shrubs ("frigana”). 2 Moderately slanting slopes with Andropogon. 3 - Slanting mountain tops with meadows and steppes. 4 - Gorges with dry shrubs ("shibliak"). 5 - Gorges with forest derivates (oak forest).

In the soils of the slanting tops with southern exposition presented as mixed grass meadows the maximum hydromass amount is $676 \mathrm{t} / \mathrm{ha}$ and the mean value is $633 \mathrm{t} / \mathrm{ha}$. In the $0-10$ $\mathrm{cm}$ soil layer the hydromass amount is $184 \mathrm{t} / \mathrm{ha}$, in $10-35 \mathrm{~cm}$ layer it is $327 \mathrm{t} / \mathrm{ha}$ and in $35-100 \mathrm{~cm}$ soil layer it is $195 \mathrm{t} / \mathrm{ha}$.

In the soils of the facies on the moderately slanting, southern exposition slopes the maximum hydromass amount is $935 \mathrm{t} / \mathrm{ha}$, while the mean value is $862 \mathrm{t} / \mathrm{ha}$. In the geohorizons of these facies the hydromass amounts are different. In the $0-10 \mathrm{~cm}$ soil layer it is $275 \mathrm{t} / \mathrm{ha}$, in the $10-40$ $\mathrm{cm}$ layer it is $330 \mathrm{t} / \mathrm{ha}$ and in the $40-100 \mathrm{~cm}$ layer it is 160 $\mathrm{t} / \mathrm{ha}$.

In the soils of the facies of the gorges in the southern exposition slopes presented as shrubbery and mixed grass meadows the hydromass amount is $1781 \mathrm{t} / \mathrm{ha}$. In the $0-5 \mathrm{~cm}$ soil layer it is $2156 \mathrm{t} / \mathrm{ha}$, at $5-30 \mathrm{~cm}$ depth it is $637 \mathrm{t} / \mathrm{ha}$ and at 
$30-100 \mathrm{~cm}$ depth the hydromass amount is $987 \mathrm{t} / \mathrm{ha}$.

In the facies of the gorges with broadleaf forest the hydromass amount in the soil is $2729 \mathrm{t} / \mathrm{ha}$. In the $0-25 \mathrm{~cm}$ soil layer the hydromass amount is $1083 \mathrm{t} / \mathrm{ha}$, at $25-60 \mathrm{~cm}$ depth it is $1310 \mathrm{t} / \mathrm{ha}$ and at $60-100 \mathrm{~cm}$ depth it is $336 \mathrm{t} / \mathrm{ha}$.

On the southern exposition steep slopes with beech and hornbeam forest the hydromass amount is $1404 \mathrm{t} / \mathrm{ha}$. The hydromass amounts in separate geohorizons are different. In the $0-100 \mathrm{~cm}$ soil layer it is $945 \mathrm{t} / \mathrm{ha}$.

In the gorges of broadleaf forest on the slanting top with southern exposition, where beech trees and tall herbaceous plants are presented, the hydromass amount in the soil is $1585 \mathrm{t} / \mathrm{ha}$. In the $0-10 \mathrm{~cm}$ soil layer the hydromass amount is $307 \mathrm{t} / \mathrm{ha}$, at $10-40 \mathrm{~cm}$ depth it is $729 \mathrm{t} / \mathrm{ha}$ and at $40-100 \mathrm{~cm}$ depth it is $550 \mathrm{t} / \mathrm{ha}$.

On the southern exposition slanting top with beech forest and shrubbery the hydromass amount in the soil is $670 \mathrm{t} / \mathrm{ha}$. In the $0-10 \mathrm{~cm}$ soil layer it is $188 \mathrm{t} / \mathrm{ha}$, at $10-40 \mathrm{depth}$ it is $268 \mathrm{t} / \mathrm{ha}$ and at $40-100 \mathrm{~cm}$ it is $385 \mathrm{t} / \mathrm{ha}$.

On the moderately slanting slope with southern exposition, where beech forest and grains and herbaceous plants are presented, the hydromass amount in the soil is $1597 \mathrm{t} / \mathrm{ha}$. According to the geohorizons the hydromass amount at 0-10 cm depth is $429 \mathrm{t} / \mathrm{ha}$, at $10-40 \mathrm{~cm}$ depth it is $108 \mathrm{t} / \mathrm{ha}$ and at $40-100 \mathrm{~cm}$ depth it is $100 \mathrm{t} / \mathrm{ha}$.

\section{Conclusions}

The above data show that in the natural-territorial complexes of the subalpine and upper-mountain forest landscapes the hydromass amounts depend on humidity and pedomass amount in separate geohorizons of the soils. Besides, hydromass amount in soil is influenced by the following factors: exposition and declination of the slope, the thickness of the soil profile, behaviour of moisturizing, projection vegetation cover and facies, nano-forms of the relief.

The obtained data make it obvious that in facies with northern exposition and less slanting surface the amount of hydromasses in the soil is significantly more than in the facies with southern exposition and steeper surface. The thicker is the soil profile, the more hydromass amount is in it. In the facies of flattened tops there are more underground flows and less surface flows of moisture. Therefore, there is more hydromass amount in the facies of flattened tops. The data show that the more there is projective vegetation cover in the conditions of one and the same vegetation cover, the more is the hydromass amount in the soil. More moisture is observed in the facies under arboreal plants compared to the ones with herbaceous plants. At the same time, the amount of hydromasses highly depend on the nano-forms developed in the macro-forms of a relief in the conditions of one and the same exposition and projection vegetation cover: gorges, abysses, hollows, e.g., the gorges developed in the facies of moderately slanting slopes are distinguished by more amount of hydromasses in the soil compared to the faces they are located in.

Thus, high amount of hydromasses is characteristic of the gorges on the southern exposition slopes (more than 2000 $\mathrm{t} / \mathrm{ha})$. The hydromass amount is also high (1500-2000 t/ha) in the beech forests in the natural-territorial complexes of the northern and southern exposition slopes. The amount of hydromasses is low (500-1000 t/ha) at the top of the Ialno Ridge and the subalpine meadows in the natural-territorial complexes of the southern exposition slopes. The same hydromass amount is observed in the vegetation semiassociations in the natural-territorial complexes of the slopes of the White Cliff. The hydromass amount is the least (less than $500 \mathrm{t} / \mathrm{ha}$ ) in rocky natural-territorial complexes.

Among the natural-territorial complexes the northern exposition slopes with forests of dead vegetation cover and beech trees is distinguished by the highest humidity $(0.38$ $\mathrm{t} / \mathrm{ha}$ ). The lowest value is observed in the southern exposition slopes with subalpine vegetation cover $(0.18 \mathrm{t} / \mathrm{ha})$.

\section{Acknowledgements}

This research would not have been possible without the support of many people and also without using many researches done by the staff of the Geographical Department (Ivane Javakhishvili Tbilisi State University). We thank the colleagues from Martkopi Physical-geographical Station, who worked there once and provided this research by data that greatly assisted the work.

\section{References}

[1] N. L. Beruchashvili. Geophysics of Landscapes, Moscow, High School, 1990, p. 287 (In Russian).

[2] R. V. Maghlakelidze. States of Soils and Natural-territorial Complexes: Analysis of Interdependence, Tbilisi, Publishing House Universal, 2005 (In Russian).

[3] D. N. Nikolaishvili. Spatial-temporal analysis of landscapes of Georgia. Tbilisi, 2009 (In Gerogian).

[4] N. L. Beruchashvili. The Caucasus: Landscapes, Models, Experiments. Tbilisi: UNEP, Grid-Arendal, World Bank, 1995 (In Russian).

[5] N. L. Beruchashvili. Methodology of Landscape-geophysical investigations and mapping of the conditions of Naturalterritorial complexes. Tbilisi, 1983 (In Russian).

[6] T. Dekanoidze, R. Maghlakelidze R., Physical-Geographical Analysis of the Ialno Fixed Station and Natural-Geographical Complexes. Iv. Javakhishvili Tbilisi State University, Transactions, Geography-Geology, 355, Tbilisi, Publish. House of Tbilisi State University, 2003, pp. 357-369 (In Georgian). 